\title{
The role of competitive potential in strengthening the economic potential of the enterprise
}

\author{
Rakhimberdiev Ismail Ubaydullaevich, \\ PhD in Economics, Associate Professor of the Department of "Accounting" \\ Tashkent State Transport University
}

\begin{abstract}
Today, the experience of many developed and leading countries in the world economy proves that achieving competitiveness and access to world markets, first of all, consistent economic reform, deepening structural transformation and diversification, rapid development of new high-tech enterprises and industries supply, modernization of existing facilities and acceleration of the process of modernization of equipment.
\end{abstract}

Keywords:

high-tech enterprises, internal potential, business development strategy; economic, market, financial, resource, production, labor, stock, innovation, investment, information, intellectual, organizational, a wide classification of potential types such as strategic potential, management potential, synergistic potential.

Article Received: 18 October 2020, Revised: 3 November 2020, Accepted: 24 December 2020

The successful development of any enterprise depends on the effective use of its own internal potential. It is the capabilities of an enterprise that determine how efficiently and successfully it can grow its business in the future. This means that the development of enterprises and the growth of their market value occurs only when there is a common potential. Therefore, the formulation and implementation of business development strategy is based on the capacity of the enterprise.

Problems related to the potential of economic systems, the efficiency of their formation and use in the twentieth century

It was widely studied in the $60 \mathrm{~s}$ and $70 \mathrm{~s}$. Research has been conducted to reveal many aspects of "potential" as an economic category: economic potential, production potential, resource potential, market potential and other concepts.

When thinking about potential theory, it covers a wide range of ways to increase the efficiency of its use: economic potential, market potential, financial potential, resource potential, production potential, labor potential, stock potential, innovation potential, investment potential, information potential, intellectual potential, organizational potential, a wide classification of potential types such as strategic potential, management potential, synergistic potential, etc. has been used.[1]

The existence of several types of potential is their ability to generate income in the process of economic activity as enterprise assets. As long as the economic potential of the enterprise serves to ensure its financial stability with the sources of its formation, the availability of material and intangible, financial and labor resources in accordance with the main purpose of the business, the problem of managing its economic potential will always remain relevant.

Based on the analysis of scientific views aimed at highlighting the essence of economic potential, they can be divided into the following approaches:

1. Approaches to economic potential as an aggregate of the business capacity of the enterprise. The emphasis is on disclosing the possibility of production of goods and services, describing the direct production capacity of the enterprise and methods of its use.

2. Approach to economic potential as a resource pool at the disposal of the enterprise. 
This approach addresses the issues of rational use of logistics, natural, labor, financial, information and other resources as components of economic potential.

3. Views on the economic potential of the enterprise as an economic efficiency that can be achieved through the efficient use of existing production resources in the future. In turn, economic potential refers to economic strength and is characterized by the fact that an enterprise has reached a certain level of development in a given period.

4. The approach to economic potential is considered from the point of view of production relations inherent in any socio-economic system, and the possibilities of the participants of economic relations in the process of creating material benefits are explored.

In the economic literature, there are many studies devoted to the interrelated nature of concepts such as "economic potential" or "production potential". A.N. Azriliyan[2] defines "economic potential" as a combination of production and economic activities of the enterprise, production of goods and services, meeting the needs of the population and society, ensuring the development of production and consumption. "Production potential" is interpreted as the possible volume or capacity of production using the available resources.

In our opinion, the approach to economic potential in terms of economic resources that can be used by the enterprise in certain conditions, on the one hand, and the ability to produce products and services on the basis of available resources to carry out certain economic activities, on the other hand.

Associate Professor M.N. Ravshanov,[3] who in previous years worked at our department on a part-time basis, in his monograph in defining the term "economic potential" cited the main features that distinguish it from other categories:
- economic potential - a category that describes the capabilities and capabilities of the system under analysis;

- capacity is characterized by a certain set of resources;

- The capabilities and capabilities of the system depend primarily on the nature and characteristics of socio-economic relations and the interaction between individuals, enterprises, government agencies involved in the economic process;

- The purpose of this relationship is the formation of needs and their maximum satisfaction through the rational use of resources and production.

Thus, economic potential means the aggregate capacity of the enterprise to form and maximize the needs of society in products and services through the rational use of available resources.

It should be noted that economic potential is not determined only by the availability of economic resources, as economic growth is ensured through the pooling of resources and their efficient use. Accordingly, sustainable economic growth is directly related to the qualitative and quantitative characteristics of the total economic potential and the level of utilization of economic resources at the disposal of the enterprise.

Since economic potential is a multifaceted category, it can be said that the growth and development of the overall economic potential is not enough to qualitatively and quantitatively assess the resource potential of the enterprise, and the problems related to increasing the efficiency of their use and rational use.

In this context, the economic potential is:

- the current level achieved by the business entity in the development of its economic activity;

- At a certain level of production development, we consider it expedient to study the enterprise as a potential that will provide the maximum possible level of production in the future, using its potential and resources wisely. 
Thus, economic potential can be understood as the formation of demand for its products and services and the cumulative capacity to meet it to the maximum, using the available resources wisely. Its effective use is to achieve the most efficient conversion of available resources into material wealth.

The priority application of marketing principles in today's market conditions requires the study of the interrelationship of the structural structure and elements of economic potential.

L.V. Strelkova and Yu.A. Makusheva describes the economic potential as "the ability to ensure long-term performance and strategic goals through the use of available resources." G.I. Usanov connects economic potential with market potential, describing the enterprise as an opportunity to produce goods and services under the influence of market conditions, emphasizing that it determines its current or future competitive position.

G.B. Kleiner defines potential (economic and social potential) as a set of enterprise resources and capabilities, defining the prospects of its activities in different scenarios of the external environment, including technical, technological, property and financial, resource, market, research and other potentials in the form of interconnected complexes.

Summarizing the above, the economic potential of the enterprise is an integral potential that summarizes the market, production, financial, scientific and technical capabilities of the economic system.

The basis of economic potential is the production capacity, the decisive factor of which are various forms of material, financial, labor, intellectual and other resources. However, practice shows that in theory, enterprises with the same production capacity do not have the same economic potential. That is, their level of utilization of production capacity may be different, or the income they may receive even when the production volume of the product is the same. That is, the income received here is of primary importance.

The economic potential of an enterprise means the sum of all its internal capabilities for its effective operation, which in certain cases may be fully or partially realized or may not be used at all.

According to I.V. Kuts, [4] the concept of market potential is multifaceted and can be used in conjunction with the economic potential and competitive potential of an enterprise.

Market potential is the ability of an enterprise to use its potential under the influence of external factors, and every business entity in the market has such opportunities. The correct assessment of market potential should be taken into account in determining the strategy of the enterprise, allowing to determine the internal hidden reserves of the enterprise, the functional aspects of increasing production efficiency.[5]

The production capacity of the enterprise must be directly adaptable to the constant changes in the market, and it is focused on the production of competitive products or services aimed at meeting the changing needs of consumers. Its market position is determined by its "competitive potential".

Competitiveness is a key factor in successful trading in a market economy, which reflects its superiority and speed over others.

Competition is a category with philosophical, economic, social aspects and can be applied to a variety of objects, including products, enterprises, organizations, industries, regions and countries. At present, the struggle for the consumer is carried out not only in the context of quality, price, operating costs, which represent the product and its characteristics, but also at the enterprise level, in the context of coordinating consumer needs and requirements for their products.

Competitiveness of an enterprise means that it produces a competitive product using its own resources, production and management capabilities. At the same time, competition 
integrates the characteristics of the structural structure of enterprises and the formation of the management system, the factors of development. The process of creating a competitive advantage within each enterprise is ultimately the basis for strengthening the national economy.

It is known from the economic literature that product competitiveness is a relative description of the technical, economic and operational performance of a product, which includes a complex assessment of its production, commercial, organizational and economic performance in relation to market requirements or other product characteristics.

Competition is seen as a driving force to improve product quality, reduce costs, and increase labor productivity. When supply exceeds demand, competition arises not between enterprises but between their products.

While having a competitive advantage is an economic reason, competitiveness is a consequence of it. The competitive potential of the enterprise serves as the basis for ensuring that both of them operate as an economic category. That is, competitiveness - if there is potential, the achievement of competitive advantages - can be recognized as the degree to which this potential is used.[6]

A group of researchers[7] define the competitive potential of an enterprise as internal and external competitive opportunities that can shape competitive advantages using material and intangible resources and ensure effective competition.

Competitive potential is the ability of an enterprise to realize its potential in the market as fully as possible at the expense of a certainly regulated set of internal and external resources and to achieve a synergistic effect using this set of resources.[8]

In some studies, competitive potential has also been described as a set of resources and opportunities,[9] an integral part of overall capacity,[10] and a factor of innovation and flexibility.[11]

Based on the results of our research on competitiveness:

- Availability of resource organizers and opportunities to own them, forming a competitive potential;

- the availability of methods, techniques and tools that in practice turn the competitive potential of the enterprise into its competitive advantages;

- the ability to assess the competitive potential of the enterprise and compare it with the performance of competitors;

- It should be noted that the main conditions for the formation and development of competitive potential are the ability to take into account the impact of environmental factors and adapt the company's activities to changing market conditions.

Thus, the enterprise can take a competitive position in the market in a favorable external environment, forming a competitive potential at the expense of internal capabilities. This requires the development of key areas of development strategy based on limited access to internal resources

Table 1.1 Components of competitive potential and the main directions of their development

\begin{tabular}{|l|l|l|}
\hline$\#$ & $\begin{array}{l}\text { Approximate } \\
\text { elements of } \\
\text { competitive } \\
\text { potential }\end{array}$ & \\
\hline 1. & Marketing & - organization and conduct of marketing research; \\
\hline
\end{tabular}




\begin{tabular}{|c|c|c|}
\hline & potential & $\begin{array}{l}\text { - to study consumer behavior and influence the formation of their } \\
\text { requirements; } \\
\text { - Improving the system of marketing information and communications; } \\
\text { - application of modern means of product promotion in the market; } \\
\text { - benchmarking. }\end{array}$ \\
\hline 2. & $\begin{array}{l}\text { Innovative } \\
\text { potential }\end{array}$ & $\begin{array}{l}\text { - Accelerated application of scientific and technical achievements in } \\
\text { production; } \\
\text { - organization of research departments on the basis of the enterprise; } \\
\text { - Involvement of different levels of staff in the process of innovation } \\
\text { development. }\end{array}$ \\
\hline 3. & $\begin{array}{l}\text { Resource } \\
\text { potential }\end{array}$ & $\begin{array}{l}\text {-use of modern and economical means of production; } \\
\text {-increase fund return, reduce fund capacity; } \\
\text { - optimization of production capacity; } \\
\text { - optimization of production and other costs; } \\
\text { - Accelerate the turnover of working capital; } \\
\text {-reduction of working capital per unit of output; } \\
\text { - renewal and expansion of production assets through reinvestment of } \\
\text { profits; } \\
\text {-improvement of product quality control system: } \\
\text {-introduction of quality management in management; } \\
\text { - optimization of staff and reduction of staff turnover; } \\
\text { - training and retraining of staff; } \\
\text { - effective organization of the system of material and moral incentives for } \\
\text { employees; } \\
\text {-improvement of relations with suppliers and logistics system. }\end{array}$ \\
\hline 4. & $\begin{array}{l}\text { Business } \\
\text { potential }\end{array}$ & $\begin{array}{l}\text {-introduction of corporate values and development of organizational culture } \\
\text { at the enterprise; } \\
\text {-creation of a healthy internal competitive environment between } \\
\text { departments and employees; } \\
\text {-formation of a healthy spiritual and mental environment in the community; } \\
\text {-implementation of social support programs, etc. }\end{array}$ \\
\hline 5. & $\begin{array}{l}\text { Market } \\
\text { potential }\end{array}$ & $\begin{array}{l}\text {-find additional needs for enterprise products and turn them into demand; } \\
\text { - Improving the system of incentives to attract customers; } \\
\text {-development of new market segments. }\end{array}$ \\
\hline
\end{tabular}

As a result of research, it can be concluded that the competitive potential of the enterprise as an integral part of economic potential forms the economic potential at the strategic level in coordination with the following functional components: production, financial, marketing, organizational, managerial and innovative capabilities.

Competitive capacity building is a dynamic process, the use of which:
- implementation of expansion of production capacity in accordance with its growth rate:

- ensuring compliance with the principles of continuity and comprehensiveness of the formation of competitive potential;

- effective use of competitive potential to meet the demand for products and services as much as possible within the available resource opportunities and to focus on obtaining the highest economic benefits; 
- achieving full satisfaction of the material potential of the resource potential of the competitive potential;

- Achieving adaptability of competitive potential to changes in the external environment.

It follows that the effectiveness of the system of formation and management of the competitive capacity of the enterprise is determined primarily by the level of capacity utilization, production and sales, product range, quality, market share, sales price and geography and sensitivity to changes in market demand.

In short, competitiveness is formed on the basis of competitive potential, and due to the competitive advantages gained, its current level reaches the maximum level of potential. If the competitiveness of the enterprise or its services is not at the required level, using the full potential in a given competitive environment, first of all, measures will be developed and implemented to increase the competitiveness and its realization.[13]

\section{References:}

[1] Karsuntseva O.V. Methodological approaches to the assessment of production potential // Vestnik Universiteta / Gosudarstvennyy Universitet upravleniya. 2013. -№5.-S.126-132.

[2] Big economic dictionary / ed. A.N. Azrilian.-7th ed. add. and revised $-\mathrm{M}$.: Institute of New Economy, 2007.- 1472 p.

[3] Ravshanov M.N. Economic potential of road transport complexes: problems and solutions. -T.: ME, 2012. - 209 p.

[4] V.I. Kuts Industrial modernization as the basis for increasing the competitiveness of the national economy. Abstract dissertation. doc. econom. sciences. -M :, MIEM, 2012 from 51.

[5] Qodirov T.U. Road transport competitiveness: organizational and economic mechanisms. Monograph. -T .: "Yangi asr avlodi", 2013. 256 p.
[6] Kadyrov T.U. An approach to assessing the use of the competitive potential of motor transport enterprises // Journal "Successes of modern natural science", -M :, 2013, - No. 12. - P.94-98.

[7] Arenkov I. A., Salikhova Ya. Yu., Gavrilova M. A. Competitive potential of the enterprise: model and development strategies // Problems of modern economy, no. 4, 2011.

[8] Romanova O.S. The concept of forming the competitive potential of enterprises // Modern competition, No. 6, 2007.

[9] Voitsekhovskaya I.A. The potential of the enterprise as the basis of its competitiveness // Problems of the modern economy - №1, 2006.

[10] Erokhin D.V., Galushko D.V. Theoretical foundations for assessing the competitive potential of an industrial firm // Bulletin of the Bryansk State Technical University. No. 4, 2006.

[11] Barinov V.A., Sinelnikov A.V. Organization development in a competitive environment // Management in Russia and abroad. No. 6, 2000.

[12] 12. Qodirov T.U. Competitive potential of the enterprise and approaches to its assessment.//Journal "Exchange-expert". Tashkent, 2013. - №3. - B. 3-7. 
